\title{
トロイデ火山の放射状節理について 宮城県鳴子町半俵山の例
}

村 山

トロイデ火山の形成機構の説明については, Reyer (1888) の実験結果による内生的膨張 (endogenous expansion) が一般的であり，わが 国の火山地形学でもトロイデ形成の説明によく 用いられ，その証拠として玉方ぎ状の流理 （久野 1960，波辺 1962） や節理（Ollier 1969） があ け゚られている。溶岩の噴出による形成機構に ついては，Rittmann (1961) は, 第三紀の Roche de la Tuiliére 火山体の柱状節理の例 をあげ, Ollier は, 不規則状節理や塊状節理 によってニュージーランドの Tarawera 火山の 形成を説明しているが，いずれも溶岩の賴出方 向之節理を一致させ，浚食による露頭の平闾的 な面にあらわれた節理から論じている。しか し，放射状節理の例はあげていない。

トロイデ形成機構には，上述以外に，潜在円 頂丘 (Cryptodome, 例として明治新山) や成層火山 などによるものもあるが，ここでは，酸性溶岩 による形成機構だけにとどめたい。

鳴子ダムの北東約 $1.5 \mathrm{~km}$ 地点に位㯰する半 俵山は, 石英安山岩から構成され, 中新統緑色 凝灰岩の蟹沢 㬝 (半俵山南簏の沢に露頭がある) 上 に噴出したもので，第三紀のものといわれてい るが (地質調査所 1958)，基盤との関係や岩質・ 節理などから潟沼付近の第四紀火山に類似した 点がみられる。標高 $591 \mathrm{~m}$ の山体の中心部は柱 状節理であるが, その部分から周辺にかけて種 々な角度に放射状節理を呈している。節理面に 対して垂直面は, 直径 $40 \sim 60 \mathrm{~cm}$ の六角形また は方形になっている。構成岩石の新鮮面は帯緑 黒灰色であるが，風化面は明黄褐色あるいは帯 白褐色を呈し，六の厚さは 2〜3cm になってい
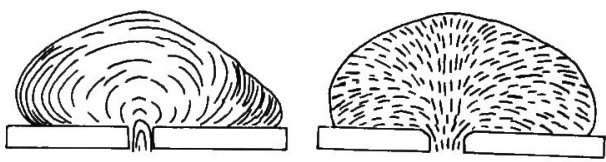

F!g. 1. 左 溶岩の内生的膨脹によるトロイテ形成 (Reyer による)

右 溶岩の放射状噴出によるトロイテ形成 (半俵山の例)

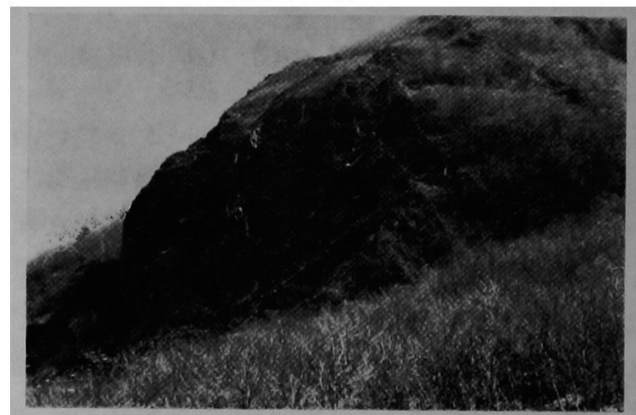

Fig. 2. 放射状節理の周辺露頭（半俵 山北端）

る。このよらな放射状節理は，Rittmann や Ollier の示寸例から, 溶岩の放射状嘖出によっ て山体が形成されたことになる。その他潟沼周 辺の第四紀火山体にも放射状節理を有するもの がある。このよらなことから，酸性溶岩による トロイデ火山を下に示したよらに分類すること ができる。

(1971.8.20 受理)

\section{文献}

地質調查所（1958）：鬼首図幅

久野 久 (1960)：火山および火山岩，岩波書店

Ollier, C. (1969) : Volcanoes, The Mit Press.

Reyer, E. (1888) : Theoretische Geologie, Stuttgart.

Rittmann, A. (1961): Volcanoes and their Activity, Interscience Publishers.

渡辺 光 (1962)：地形学 (現代地理学体系) 古今 書院

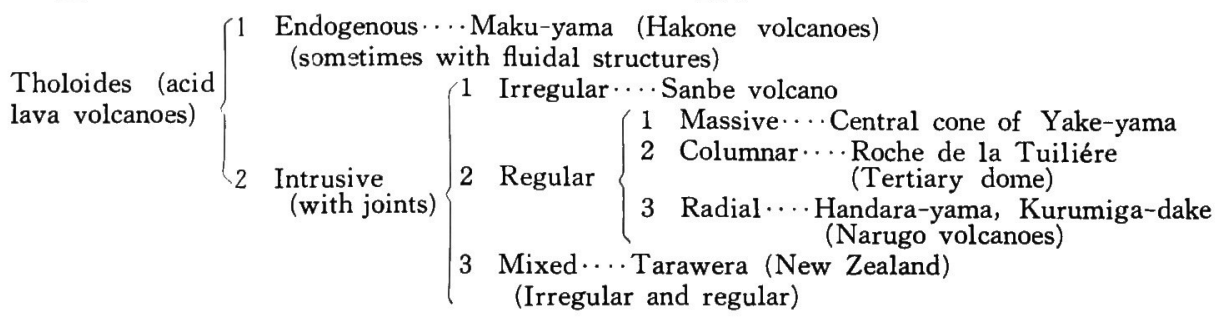

\section{On the Radial Joints of Tholoide Volcano - A View in Handara-yama- Iwao Murayama}

A tholoide generally speaking grows primarily by endogenous expansion according with Reyer's experiment (1888). While, the Handara-yama, and a small volcanic body on the northwestern flank of Kurumiga-dake in the Narugo volcanoes are formed by intrusion of lavas in radial pattern.

Tholoides also lend themselves to a division into types on the basis of the kind of intrusion of lavas, as shown in the table. 